\title{
Global Branded E-Government Stakeholder Interaction
}

\author{
Alptekin Erkollar \\ ETCOP Europe, Klagenfurt, \\ Austria
}

erkollar@etcop.com

\author{
Birgit J. Oberer \\ Yeditepe University, Istanbul, \\ Turkey
}

oberer@etcop.com

\begin{abstract}
E-government services - electronic services made available by governments to stakeholders, citizens, businesses or governmental authorities - and their type of creation, duration and volatility, are showing dynamic changes in the public sector. E-government services cover all governmental measures at the levels of unions, states and local governments for qualitative improvement in citizen's various spheres of life and the business environment; for optimization of business processes within the administration; and for improvement of public appearance within an international competitive environment. To compete globally, public authorities are having to reconsider how to make their services to stakeholders more competitive. One aspect of becoming more competitive and differentiating from competitors in the market is investing in global branding for the whole process of stakeholder interaction. In this paper, we provide an implementation guide for egovernment stakeholder interaction strategies.
\end{abstract}

Keywords: government, e-government, stakeholder, brand, communication, interaction.

\section{Introduction}

Influence of information technology (IT) affects today's world and has a huge impact on the development of governmental organizations. Governments have new tasks to fulfil and new possibilities as to how to implement those tasks. E-world applications can be seen as a base for establishing e-government interaction services, considering the international view that all global communication incentives and e-government services provided to a government's stakeholders need to be branded (Erkollar \& Oberer, 2008).

In this paper, an implementation guide for e-government stakeholder interaction strategies is presented. After a short overview of electronic governmental services that public authorities generally offer and the government's stakeholders, we emphasise the importance of global communication for governments and their authorities and show how governmental authorities and govern-

Material published as part of this publication, either on-line or in print, is copyrighted by the Informing Science Institute. Permission to make digital or paper copy of part or all of these works for personal or classroom use is granted without fee provided that the copies are not made or distributed for profit or commercial advantage AND that copies 1) bear this notice in full and 2) give the full citation on the first page. It is permissible to abstract these works so long as credit is given. To copy in all other cases or to republish or to post on a server or to redistribute to lists requires specific permission and payment of a fee. Contact Publisher@InformingScience.org to request redistribution permission. ments can design and implement global branded stakeholder interaction. A global brand is one which is able to reflect the same set of values all around the world. Specific attributes of the products and services public authorities offer, as well as the style and character of the brand need to be appropriately designed and the requirements evaluated and implemented. Global branding guidelines for developers and decision 
makers are introduced. The $7 \mathrm{C}$ factor method, required for designing and implementing interaction strategies within the public sector, is also presented.

\section{Governmental Services}

The term e-government comprises online services provided by a government and its authorities that are made available by the government to its stakeholders - citizens, businesses or governmental authorities. E-government has the potential to improve the relationship between its administration, citizens and business, and includes all administrative measures at all levels (Oberer, 2002).

Potential advantages of e-government are (Wounger, 2003): lower service delivery costs, enhanced knowledge sharing and collaboration, improved internal decision-making, increased public accountability, meeting of citizens' expectations for greater information access and increased citizen satisfaction levels.

\section{Government Communication and Stakeholder Interaction}

The main functions of government communication are informing and engaging partners, and advocating and persuading those partners on policies and reforms. Enhanced citizen participation is one key indicator of the effectiveness of government communication. However, many countries lack information provision and enable citizen participation either insufficiently or not at all. Neglect or non-execution of information provision to the public represents a barrier to governance. Undervaluing the benefits of improved government communication has a serious multiplier effect. Government communication should involve the provision of customer-oriented services and a means for citizens to provide the government with feedback regarding the services provided (Erkollar, 2008).

Communication is an important government function. It is the means for improving the three principle elements of government (Melicher, 2007): Accountability - explaining government stewardship and providing mechanisms to hold governments accountable; Effectiveness - building broad support and legitimacy for programs; and Responsiveness - knowing citizens needs and responding to them.

Working with stakeholders has been gaining importance in the public sector environment. Stakeholders have an increasingly significant role in the delivery of governmental services and in contributing to the development of governmental policy. Governments have begun to recognize the role played by stakeholders and to work in partnership with these individuals and organizations to produce benefits for all stakeholders. Thus, stakeholders should be involved in the process of developing, implementing and delivering governmental policies. Governments need to be made aware of the incentives for communicating and interacting with stakeholders because they often do not realize that communication is fundamental to their functioning. Moreover, governments have to demonstrate the contribution of government communication to improved governance and development outcomes (Oberer, 2008).

Government communication ought to be more than a basic tool for crisis management. It should involve, for example, consulting with policy makers of issues, raising awareness, changing behaviour, achieving consensus, supporting civic education, general transparency and listening to society attitudes and changes in values, traditions and general behaviour (Erkollar, 2008). Governments may lack qualified communications staff, leading to a lack of structure for communication, how to generate governmental knowledge, how to find relevant stakeholders and how to provide information and communicate with the stakeholders. Communication means providing 
information and the opportunity for feedback. Much of the work to improve government communication contains addressing structural issues. For this, a firm understanding of governmental policies is necessary. Meanwhile, for governments it is necessary to understand the key factors and basic rules of journalistic work (Melicher, 2007).

\section{Government Branding}

The American Marketing Association defines a brand as a name, term, sign, symbol or design, or a combination of these intended to identify the goods and services of one seller or group of sellers and to differentiate them from those of other sellers. Branding can be defined as a output generating process. The outputs are a brand and a brand identity for differentiating products, services and corporations in an attractive way at the same time as meeting regulatory requirements. Brands are critical marketing and communication assets. It is important to spend time investing in researching, defining, and creating a brand. Clear and consistent brand messages encourage interest from an organization's stakeholders (Lakeworth, 2008).

Many governmental agencies have adopted names and logos to give them a unique character and style. This gives the impression that the agencies are energetic and developing, providing a positive impression to the stakeholders. On the other hand, the unique style may give the impression that the department is not part of the government, which may cause confusion to stakeholders. Generally, one logo should be designed, presenting a single, recognizable brand for the government. This would make it easier for stakeholders to recognize the government's products, entities and services, and to be able to distinguish them from other levels of government as well as from the private sector (Huntington, 2007).

A global brand is the brand name of a product, service or bundle of products and services with worldwide recognition. Global branding is the process of generating and implementing a global brand, which includes control structures as well as double response loops (Huntington, 2007). Global brands provide the advantage of economies of scale in terms of generation and recognition of the brands. While the product, service, bundle of products and services or the brand itself may remain unchanged, marketing and stakeholder communication have to consider local markets and their conditions and limitations. Thus, the resulting marketing and communication strategies have to be tailored accordingly.

\section{Guidelines for Branded Stakeholder Interaction}

\section{Brand Development Process}

To define a brand, governments have to be aware of some of the circumstances and conditions regarding their products, services, customers and internal matters. The following questions have to be answered as a basis for defining the brand (Lakeworth, 2008):

- Which products and services are offered and what is their quality?

- What are the core values of the government and its authorities?

- What messages does the organization want to send to the stakeholders?

- What is the structure of the target markets (local, regional, national, international)?

- Which characteristics of the governmental services will attract the target markets?

- What is the special profile of the government and its authorities? 
Purpose of government branding: The $7 \mathrm{C}$ factors (the $\mathrm{C}$ stands for the first letter: of the following seven terms) - comprehensiveness, currentness, client-orientation, clarity, courtesy, compatibility, cross-linking - are considered the standard guideline for web design for governmental agencies and other organizations regarding branding for internal and external communication (Erkollar, 2007).

Objectives: The objectives are to increase the efficiency and effectiveness of government branding and the stakeholders' awareness of government programs, products, services and policies.

Policies: All governmental agencies have to carry the government brand as their primary brand for external communication. An approved agency logo can be used as a secondary brand. Where the brand would be inappropriate because of its size, the name of the government should be written instead (Lakeworth, 2008).

\section{Critical Conditions}

There are certain critical conditions for the successful implementation of branded e-government strategies, as summarized below (Oberer, 2002).

Demand orientation: The demand for electronic governmental services has been proven empirical. The main interest for a governmental service user is simple and fast information procurement and transactions to simplify contact to the governmental authorities. The use of electronic administrational services therefore should be demand and impact orientated.

Organizational conditions: The following organizational conditions should be considered: Redesign of administrational processes and structures so that the development of e-government and the redesign of administrational processes and structures agree with each other and are synchronized, coordination of organizational and technological redesign and technical organization decisions at all levels and synchronization of internal changes and external administration services.

For providing information to stakeholders, two conditions have to be true: (1) the government has developed a culture of disclosure needs; and (2) the government has relevant information needed for different communication channels (Oberer, 2008)

Main legal condition: There is a need for formulation of an information policy and definition of rules for access and use of electronic services by citizens and businesses.

Technological conditions: There has to be a distinction between the "must haves" and "can haves" for all standards, for example, technical, ethical, legal and organizational, to set a priority system for implementation (Erkollar, 2007; Oberer, 2002).

Different access media for different countries and different stakeholders may need to be considered. Since demand and communication depend on different functions, the interface structures must be designed and implemented with consideration of whether a standard application can cover all requirements or whether it should be tailor-made (Oberer, 2008).

Currently, many governments do not have the capacity to fulfil the task of one-way communication (information provision) effectively, indicating a lack in the communication structures. On the other hand, one-way communication is not enough for producing high quality governance outcomes. Two-way communication between the government and its stakeholders is needed to produce high quality governance products. The better the two-way communication structures, the higher the quality and sustainability of the governmental output. It is not enough for a government to communicate with the public about elections or political risky issues. Governments need to be made aware that a lack of communication with its stakeholders gives opposing forces the possibility to dominate the public. 
Thus, a clear structure for different communication ways is needed encompassing the following (Erkollar, 2007): Left-right information provision, right-left information provision, bi-directional communication flow, bi-directional cycle flow

Additionally, the $7 \mathrm{C}$ factors (goals) for the structure of web interfaces have to be considered (Lakeworth, 2008):

- Comprehensiveness: institutional coverage with respect to organization and functions as provided at the closest point of knowledge.

- Currentness: accuracy of static information enhanced by the correctness and relevance of changing information.

- Client-orientation: responsiveness to inquiries of clients

- Clarity: simplicity of page design

- Courtesy: reasonable load time for single pages

- Compatibility: consideration of different browser requirements

- Cross-linking: multiple access possibilities to the same information.

Ethical conditions also need to be considered, including (Oberer, 2008): providing information to constituents, generating knowledge by listening to citizens and other stakeholders, providing professional communication structures and methods, supporting public discussion and explaining the rights of citizens and working policies.

\section{Implementation Process}

An implementation framework has been developed to address all who are responsible for government communication and (global) branding issues within an administration including legal, organizational and technical aspects. The guide can be seen as a meta-model for implementing global branded e-government strategies. The meta-model needs to be adjusted to specific circumstances. Attention has focused on the consideration of administrational targets, the evaluation of critical criteria for governmental online services and the needs of global communication and global branding. The underlying e-government process is a dynamic one with steady organizational and technical changes and adjustments. Therefore, of special interest for adjustments are changes in the legal conditions for services, development of demand for a service, new platforms and IT security issues. These need to be covered for a successfully implemented project management structure (Erkollar \& Oberer, 2008).

Legal requirements: Acts of parliament and international agreements should be issued for protection of the coat of arms.

Organizational requirements: It is recommended for governments planning activities in the area of global communication and branding to create the required organizational framework for realizing the plans. An office for global communication and branding should be established. The mission of this office should be the coordination of government information programs to ensure consistency in messages to promote the interests of the country abroad; to build support for and among coalition partners of the country: to prevent misunderstanding; and to inform international audiences (Erkollar \& Oberer, 2008).

Branding architecture is the organizational structure for the relationship between the main brand and the brand of subsidiaries, the various entities through which the government communicates with its stakeholders. Branding levels can be structured into level 1,2 and 3 entities. The national coat of arms is the principal identity of all level 1 entities within a governmental structure. A 
structure for a hierarchical branding identity should be developed and should guide all applications to differentiate between the three types of governmental entities. All level 1 entities, for example, the state, president, ministers and ministries, should use the national coat of arms without exception. Level 2 entities, such as transversal programs, should use their own identity certified by the national coat of arms. Level 3 entities (e.g. local authorities) should use their own coat of arms or use their own identity (e.g. constitutional institutions). For managing the branding behavior of the entities of all the levels, certain defined principles have to be considered, including responsibilities for endorsements and placement of the national coat of arms depending on the branding level and in some cases depending on the branding partner.

Technological incentives: E-government initiatives, such as Web 2.0 technologies like blogs and short message service (SMS) applications, can serve to promote improvements, as can traditional communication tools like community radio call-in shows and local television. Community media can stimulate two-way communication between civil society and the state. Communication approaches and techniques such as blogs are fundamental to the effectiveness of efforts to improve governance and direct accountability. These methods can be used to communicate with the stakeholders of governments and their authorities as well as other governments around the world, providing-for example, in cooperation with other governments or institutions - a platform for exploring the global interactions among public opinion, governance and the public sphere. With such inventions, the development of a global community can be supported by members who want to improve governance and accountabilities in their home countries. National governments can provide information, communication and transaction possibilities of people, organizations, foreign nationals and foreign nations. Generally, a global branded communication infrastructure should be designed and implemented for the government, its embassies and consultants around the world. Governments should select an experienced global provider of communication services for governmental organizations, foreign ministries and governmental offices to satisfy the governmental needs (Bartelheimer, 2009). The governments should find a single provider for the required communication infrastructure who can provide sufficient services including an international IP VPN solution, global network coverage, quality of service, high level of security, local support, a competitive service level agreement and cost-effectiveness.

\section{Conclusion}

Government departments are facing growing pressure to communicate more openly and effectively with its stakeholders. A global branded strategy for electronic governmental services in one approach enabling governments to communicate more efficiently and effectively. To establish global branded electronic services, the government needs to define its main brand, namely, the national coat of arms, and implement a structure showing all governmental departments and authorities with their rights and duties regarding the global brand. An organizational process has to be adopted for designing and implementing global branded strategies and for establishing control structures as well. Governments have to decide on the scale and characteristics of the brand. In addition, technical challenges have to be considered. A provider for the whole global communication needs to be selected and evaluated. A legal framework has to be developed and communicated for the implementation and running of the global branded communication structure. Rules have to be established for the branding and co-branding as well and structures for internal and external communication developed. Clear visual display of text has also to be developed that works across a wide range of services. A uniform national coat of arms allows the government and its authorities to protect a consistent and coherent brand to its stakeholders.

The guideline outlined in this paper provides governments with a practical framework that meets the legal, organizational and technical requirements for successful implementation of global branded e-government stakeholder interaction. 


\section{References}

Bartelheimer, G. (2009). Technologiemanagement, Vienna: Linde.

Erkollar, A. (2007, July). 7 C Factors. Paper presented at the WMSCI Conference.

Erkollar, A. (2008). Governmental governance: A structure analysis. Vienna: WN University.

Erkollar, A. \& Oberer, B. (2008). How to implement global branded e-government strategies, Marburg: Avensis.

Huntington, M. (2007). Governmental branding. How effectiveness and efficiency can be measured. New York: ASYSS.

Lakeworth, S. (2008). How important is branding to your marketing strategy? Boston: ASYSS.

Melicher, M. (2007). Communication in enterprises and governments. Government Inside, 3(24), 24-34.

Oberer, B. (2002). Classification portfolio for electronic government approaches. Vienna: WN University.

Oberer, B. (2008). The ethics of governmental communication: A case study. Klagenfurt: ETCOP.

Wounger, A. (2003). Electronic services for governments. E-Government, 4(7), 2-4.

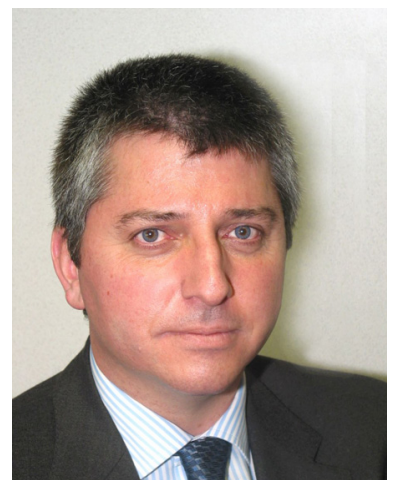

\section{Biographies}

Prof. Dr. Alptekin Erkollar is Head of the Department, Department of Business Organization and Business Informatics, ETCOP Europe. He has over 20 years of experience in academic education (Austria, USA, Turkey, Germany, Switzerland, Liechtenstein, Australia) and has written several books and journal articles in the area of eCommerce, eGovernment, project management and software reference models. His teaching and research interests include international business, business informatics and eWorld.

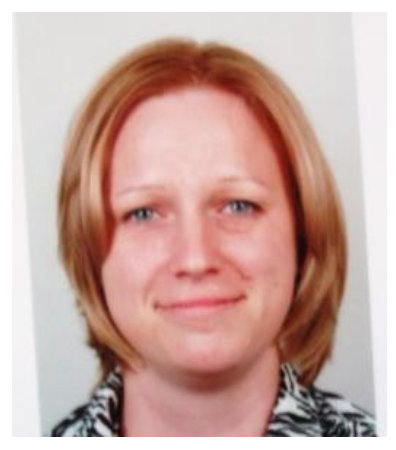

Assistant Prof. Dr. Birgit J. Oberer is faculty member of the business informatics department at Yeditepe University .Previously she has been process manager at an international telecommunications company in Austria and taught at different universities in Austria, Germany, Switzerland and USA. She has authored several books in the area of eGovernment, eCommerce and production management and contributed to American textbooks in the area of information technology and eGovernment. 